\title{
FRENCH WORK IN COMPARATIVE PSYCHOLOGY FOR THE PAST TWO YEARS
}

The zeal with which investigations in comparative psychology are being pursued in France is testified to by the contents of the Bulletin de l'Institut général psycbologique, whereof the reports of the Groupe d'etude de psycbologie zoologique form something like four-fifths. It is further witnessed by the long bibliography attached to this paper, the extent of which, however, is partly due to the fact that many of the titles refer to short communications in the Comptes rendus of the Societe de Biologie and the Académie des Sciences. In some cases the contents of these are repeated in the longer articles.

The work of Georges BoHN is, as usual of late years, the most voluminous and the most important French contribution to the science. This writer's earlier papers may be found summarized by Professor Yerkes in this Fournal, vol. I6, p. 23r. During the two years since the appearance of that summary, BoHN has devoted himself especially to experiments and observations on actinians and starfish. He has gained what he considers to be new confirmation of one of the cardinal facts upon which he has long insisted: the influence upon the present reactions of an animal of the conditions which have acted upon it in the past, les causes passees. Further, he has definitely rejected JeNNincs' conception of "trial and error" in favor of the position of LOEB, and maintains that the oscillations and variations in tropisms which have given rise to the former idea are the effect partly of the influence of past conditions, partly of that "sensibility to difference," or susceptibility to changes in the intensity of a stimulus, which LOEB assumes in addition to the tropism, and which, in BoHN's opinion, LOEB's critics have too much ignored. A special case of the influence of past causes is to be found in the preservation under laboratory conditions of certain oscillations in tropisms which coincide with tidal rhythms and with the alternation of day and night. The study of these oscillations, to which he and others had previously called attention, has been continued by BOHN, and observations bearing on the matter have been made by PIÉRON and by Drzewina. BoHn's statements regarding the preservation of the tidal rhythms in the laboratory have been received with some scepticism by L. LAPICQUE.

Of the other contributors whose names are to be found in the bibliography, PIÉRON, in addition to his work on actinians, has been making studies of the sensory factors which play a part in the life of ants, and has also been investigating the phenomenon of "autotomy," or the amputation by an animal of one of its own members. A discussion has arisen in connection with this point between him and Drzewina, the nature of which will be later explained. Faure-Fremiet has been observing the behavior of certain protozoa. LECAILLON has been continuing his studies of the instincts of spiders. HACHET-SouPLET, pursuing his conception of animal education, for which he has, with the approval of two members of the Academy, adopted the word "zoopedie," has succeeded in obtaining the vote of the Institut 


\section{Fournal of Comparative Neurology and Psychology.}

général psychologique for the establishment of a Section d'etude de dressage scientifique, the actual formation of which, however, appears to have been postponed.

We shall now take up in order the titles in our bibliography, referring to them by number, and try to indicate the important points brought out in each paper.

I. Of this article by BoHN, the substance is as follows: Those animals which show most rapid transmission of nervous impulse from one segment to others would seem to have most psychic individuality, but this is a vague and obscure concept. The degree of coördination depends on the development of the receptive sensory apparatus.

2 and 3 . Acanthia lectularia is a negatively phototropic insect. BоHN shows that when it undergoes a change of illumination, its tendency is to rotate through $180^{\circ}$ in a direction which is constant during the day, and changes towards evening. This reaction is but poorly adaptive, since under certain conditions it may lead the animal to turn toward the light. For instance, if the insect is moving along a shadow directly away from the light, and comes to the end of the shadow, it will turn through $180^{\circ}$ and thus be brought to facc the light. Again, it may either approach or move away from a dark screen, as a consequence of its turning always in the same direction at a given time of the day. The molluse Littorina, on the other hand, is always, at a given hour, attracted by a dark screen. The superior adaptiveness of Littorina's behavior may be due to the fact that in nature it is accustomed to seek shade, while Acanthia does not come out on bright surfaces at all during the day.

4 and 5. The results stated in these papers were published later in 27.

6. The results of this paper are stated in paper number 15 .

7. As between the "teleological" interpretations of JENNINGs and the mechanical explanations of LOEB, BOHN would insist on taking account of the past experience of the animal in determining tropisms.

8. This paper must be taken in connection with that by PIÉRON numbered 59 in the bibliography, and with the paper by BoHN and Pieron numbered 28 . Actinia equina closes when the sea withdraws, and opens when the sea returns. PIÉRoN found that the specimens he kept in the laboratory opened under the following conditions: when sea-water was made to run over them, when the water was agitated, when it was reoxygenated, when food substances were brought near. They closed when they had been some little time dry, when the water was deoxygenated, when they received mechanical shocks, and after grave lesion by toxic substances. In the pools from which they were taken, they expand at the mechanical agitation caused by the first wave of the rising tide that reaches the pool. They close, at falling tide, before the pool is stagnant. They thus show "anticipation," in closing before there is actual need of it. PIEron did not find, however, that rhythmic opening and closing in accord with the tides persisted in the laboratory (59). BOHN and PIERON, in their joint paper (28), explain the difference between their results in regard to this last point,-BoHN having found a persistence of the tidal rhythm in the laboratory with Actinia equina as with Convoluta roscoffensis, - by the difference in habitat between their specimens. BoнN's were taken from high on the side of a vertical wall, where the contrast between the conditions at high tide and those at low tide was very marked. Píron's were taken from pools not wholly dry even at low tide. The "anticipation" noted by Pikzon is a step towards the development of such a rhythm as that 
observed by Bонn. The actinian first responds to the stimulus of loss of oxygen or drying; then, by anticipation, to a stimulus which regularly precedes this (diminished agitation of the water), and finally to an internal, periodically occurring stimulus (28). In paper number 8 of the bibliography, Born gives a further account of the persistence of the tidal rhythm in Actinia. The specimens observed by him spontaneously opened and closed in the laboratory for two or three days. That the rhythm still existed after this time was revealed by the following facts: if an actinian was placed in a current of water, after expanding, it closed, but it closed much more readily at the time of descending tide; when kept in a current for a long time, the actinians remained closed, but opened irregularly and temporarily at the next high tide, and quite generally and persistently at the one after that; mechanical shocks had a tendency to make them open at rising tide and close at falling tide.

L. LapicQue, in paper number 43 , expresses doubt as to the reality of the periodicity thus observed. He raises the point that the rhythm impressed upon the actinians should be that of the tides on the last day of their sojourn under actual tidal influence, and that this would in the course of the next week bring them quite out of accord with the contemporary tidal periodicity. Boнn replies in paper number 9 by showing that the oscillations correspond in a general way to the contemporary tidal rhythm; and in paper number 38, with FAUvEL, demonstrates that certain diatoms (Pleurosigma aestuarii) exhibit a tidal rhythm in emergence and disappearance which continues in the aquarium. He admits that mathematical exactness in plotting the curves of such periodicities is impossible (12) (13) (18); LAPIcQUE, unreconciled, suggests that BoHN had better give up the attempt at it, if this be the case (44) (45).

10. BoHn's study of certain seaside butterflies concerns the relations between phototropism and anemotropism. Satyrus janira orients itself when at rest with head to the wind; its flight is determined by the position of the sun. The more the posterior portion of the eyes is illuminated, the more the wings are spread apart when the insect is at rest, and the more energetically they beat in flight; hence the insect flies away from the sun, especially when it is low. Vanessa cardui shows the same relation between the illumination of the eyes and the beating of the wings, only more strikingly; $V$. io also shows it, but the relation is the reverse in the case of V. urticx.

II. This article is a discussion, more or less historical, of the relations between tropisms, instincts, and intelligent acts, in which the conclusion is reached that "JFNNiNGs is wholly right in considering supposed tropisms as phenomena in general very complex. But these tropisms depend not only on the connections between organs, but on the state of the matter composing the organs. Living mattcr has a whole history which is responsible for the fact that its reactions are made in accordance with determinate rules. Selection, as Jennings conceives it, has but little upon which to exercise itself. The ideas of Jennings, far from invalidating those of LОЕв, merely supplement them."

$14,15,16,17$. These papers on the reactions of actinians may be considered together. Paper 15 includes the results of the other three. Actinia equina, as we have seen, was found to preserve a tidal rhythm in the laboratory. A day and night rhythm, usually that of opening at night and closing by day, also showed itself. The influence of habitat was indicated by the fact that the day and night 


\section{Fournal of Comparative Neurology and Psychology.}

rhythm was observable in actinians taken from pools where the tidal changes were less important. It was masked by the tidal rhythm in specimens from high rocks, but might be observed in these when the tidal rhythm had disappeared. The effect of habitat was further shown by the fact that actinians collected from sunny places showed a reverse day and night periodicity, opening by day and closing at night, while those taken from dark places seemed to suffer under the influence of light. The effect of ligbt is exhibited by the fact that actinians display more activity, the more light they have been subjected to in the past. Impurity of the water increases the effect of light. Mesbanical agitation scems to destroy a state of inertia in the animals, and may reveal a tidal rhythm. Anthea cereus and Actinoloba dianthus show a more marked response to light than Actinia equina, the former probably because it contains chlorophyll-bearing algx. A. cereus converges its tentacles towards the light; $A$. dianthus orients its column in the same direction, but the orientation is reached only after a series of oscillations which suggest trials and crrors, but in BoHN's opinion are the absolutely determined effect of past.causes, combined with "sensibility to difference" in LOEB's sense. There is a general tendency for actinians to expand under a thin layer of water: this is doubtless connected with the fact that the food supply is best near the surface. Tealia crassicornis shows the same gencral features of behavior as the other actinians mentioned.

19. The most important point in this paper is as follows. The leech observed is positively phototropic; at the outset of its movements toward the light, its orientation is precise, but the further it advances, the more it waves its body from side to side. If these deviations were "trials," they ought, BoHs contends, to diminish rather than increase in number. They are, rather, the effect of the progressive weakening of the light's attraction.

20 and 21 . These communications may be summarized in the author's own words. "An animal which has just been immersed in still water or undergone mechanical excitation, if it moves in a restricted area of a constant luminous field, shows in general a progressive and more or less rapid weakening of the effects of phototropism and of sensibility to difference. This weakening is connected with the progressive return of the animal to a state of rest. We should sec in this return, not the consequence of " fatigue or an alteration in external circumstances, but "the progressive exhaustion of the nervous effects of the initial mechanical excitation, which momentarily overcame the inertia of the animal." "In a luminous field, phototropic animals follow fatally, in a given direction, certain lines. But during a change of illumination, the animals tend to turn about upon the lines and follow them momentarily in the opposite direction, hence they may deviate for a time. Many of the supposed "trials" of JenNings might be explained by applying this law."

22. This is a summary of recent work in America and elsewhere.

23, 24, 25, 27. The echinoderms studied by BoHN were the following: Asterias rubens, Asteriscus verruculatus, Astropecten irregularis, Ophiolepsis ciliata, O. albida, Ophiothrix fragilis, Ophiocnida brachiata. The salient results may be grouped under three heads. (a) Sensibility to difference is shown by the tendency of sudden changes of illumination or of slope to change the sign of phototropism and geotropism, producing oscillations which are not properly "trials," but are as fatally determined as the tropisms themselves. Further evidence that these 
oscillations are not "trials" is to be found, BoHs thinks, in the fact that young starfish show them to a much less extent than older ones; trials should diminish with age. (b) The eyes are essential in phototropism; a starfish with one or more eyes sectioned acts as if a black screen were brought near, that is, it moves toward the wound, a tendency which conflicts in an interesting way with the general tendency to move away from a wounded point. (c) The formation of habits in the starfish is shown by the following observations. A starfish on a sunny bottom far from any shade converges its arms towards the light in order to protect itself. Those which live normally in sunny regions do this more readily than those which are accustomed to be near shade which they can seek. Further, the starfish is capable of changing the direction of its movement in two ways: by changing the leading arm, and by rotating on itself so as to give its arms a new direction. An individual may be taught to use the latter method by cutting off one or more arms, or by repeatedly stimulating an arm.

26. This paper contains notes on the reproduction of actinians by fission.

29. This article is a more or less popular lecture by BonviER on the habits of the honey-bee, in which he maintains the singular thesis that individual bees have no intelligence whatever; that intelligence is for the bee a function of the social state, and that it is displayed to a marvelous degree by a "secret committee" which regulates the affairs of the hive.

30 and $3 \mathrm{I}$. These articles by Mlle. Drzewina will be discussed in connection with numbers 62-67, as they are concerned with PIÉron's ideas on autotomy.

32. Here DRzewina shows that the fortnightly tidal fluctuations are represented by changes of phototropism in the laboratory on the part of the crab Clibanarius misanthropus.

33. Carcinus monas put down anywhere on the beach will turn and make for the water, even with eyes blackened, and with the wind from any quarter. This, Drzexina thinks, is a case of attraction by humidity, and the influence of past causes is shown by the fact that crabs from high levels are specially sensitive.

$34,35,36,37$. FAURÉ-FrémIE'T in these articles first surveys the differentiations of structure and of sensory and motor apparatus to be found in the Protozoa. He then classes the reactions of this group under four heads: local and direct response to stimulation, as the withdrawal of a pseudopod; more extended response, involving a considerable portion of the body; general response, involving movement of the entire body; and local but indirect response, such as the retraction of the stem in Vorticella when another part is stimulated. In papers number $3^{6}$ and 37 the reactions of Colpoda cucullus and Urostyla grandis are described, and the attempt is made to show that they are the resultants of the various ciliary beats.

39. FOREL thinks the following fact shows that bees have memory for time. Some bees learned to visit an out-of-doors dining-table at certain hours of the morning and afternoon during which there were sweets on the table. They continued for several days to come at these hours, although the swects were no longer placed on the table; then gradually desisted.

40. HACHET-SOUPLET suggests that we may be sure of the purely instinctive, i.e., non-intelligent, character of an act when an animal persists in trying to perform it though one of the essential conditions for its performance is lacking, as when, for example, a hermit crab tries to introduce itself into a smooth glass ball without an opening. 


\section{Fournal of Comparative Neurology and Psychology.}

4I. In presenting his request for the formation of a special section for the study of animal education, HACHET-Souplet makes some observations on the method which he considers best adapted to bring out the highest mental powers of animals: that of persuasion, consisting in explaining to the animal, by voice, gesture, or arrangement of surroundings, what it is expected to do.

42. The same writer discusses the method by which dogs are taught to rescue drowning persons.

$46,47,48$. The most important results of the last two papers are included in the first. The instincts treated are the uses of the web, the care of the young, and the courting processes. LÉcaILlon finds that the spiders observed by him show little discrimination in regard to the cocoon, but will accept cocoons of other species and different form from their own; that they are not disturbed if, while they are carrying a cocoon, its wall is cut, allowing the eggs to fall out and decidedly altering the weight of their burden; that they can distinguish at some little distance a strange female occupying their nest.

49. Marage places himself on the negative side of the discussion regarding the hearing of fishes. He tested Gobio fluviatilis, Anguilla vulgaris, Esox lucius, Tinca vulgaris, Cyprinus carpio, and Leuciscus rutilus in the aquarium, and, in free water, Alburnus lucidus. The sounds used were the vowels ou, o, $a, e$ sung successively on notes from $\mathrm{C}_{2}$ to $\mathrm{G} 6$, with energy varying from $0.00045 \mathrm{kgm}$. to $0.05 \mathrm{kgm}$., communicated through rubber tubes, the fish not being able to see the experimenter. No response whatever was obtained, though a diver $80 \mathrm{~m}$. away could hear and distinguish the sounds.

50. The chief contribution made by MarTin to the study of the tidal rhythm in Convoluta is the fact that various influences, such as repeated mechanical shocks, prolonged darkness, colored light, chemicals, etc., may inhibit the rhythm, causing "amnesia," and that "non-amnesic C mingled with a greater number of amnesic C lose their memory, while amnesic $\mathrm{C}$ mingled with a greater number of non-amnesic C imitate the oscillatory movements of the latter."

51. This is an unimportant because inexact observation of the attraction of ants to food at a distance.

52. This paper contains definitions of morphological terms and a statement of unsolved problems with regard to the instincts and mental powers of birds.

53 and 55. Pieron's study of Actinia equina begins with the question as to what stimuli provoke reaction: he finds, unlike BoHs, that light has no effect, nor has auditory stimulation. There is some response to food held very close to but not in contact with a tentacle. Contact with food produces the feeding reaction; some individuals will attach themselves to any mechanical stimulus, while others give withdrawing movements to any but a food stimulus. A portion of another actinian will not be swallowed. As regards the localization of sensibility, the tentacles are sensitive to both mechanical and chemical stimuli, as are the peristome and mouth; the foot is very sensitive to mechanical stimuli, and the column insensitive to both mechanical and chemical excitants. Varieties, individuals, and ages differ in sensibility. Foul water and drying affect the response to stimulation, as do certain internal factors, such as digestion, regurgitation, and parturition. Reaction ceases when a mechanical stimulus is repeated. Paper 55 is a study of the movements of A. equina and of their synergy.

54. This paper discusses, without reaching a positive conclusion, the problem 
as to whether the crab or the actinian started the fashion of the latter's taking up its abode on the former's back.

$56,57,5^{8}, 61$. The first of the reports by Préron to the Society of Biology regarding his studies on ants states that he has confirmed with eighteen hitherto untested combinations of species, BE'THE's experiment in which an ant was received into a foreign nest when dipped in the juices of ants from that nest. In the second paper (57), he notes various circumstances which modify the reaction to strangers. Certain species are inclined to be tolerant, such as Aphænogaster barbara nigra and Formica cinerea with regard to other nests of the same species, and Myrmecina latreillei with regard to other species. Sometimes an ant of the same nest is attacked "erroneously." Attacks are more frequent near the nest than at a distance from it. A solitary ant tends to run away rather than to attack, save in the case of a very small one mecting an ant of a larger species, when the former clings to the legs of the latter. Males do not distinguish strangers from nestmates, and a female after the nuptial flight is received in a foreign nest. There are also individual differences in reáction. Most of these modifying circumstances have an adaptive significance ( 58 ), for instance the tolerance of Formica cinerea is doubtless connected with the fact that its nests are ordinarily built close together, and that of Myrmecina may be due to its hard chitinous armor. As regards the problem of nest finding, PIÉron would distinguish three types of ants: visual (Formica fusca, e.g., which cannot find the nest when blinded), olfactory (Lasius fuliginosus, e.g.), and muscular (Aphænogaster barbara, which if carried out of its path will continue, when set down, until it reaches a point where the opening of its nest would have been found if the ant had not been moved).

$59,60,63$. We have already noted under (8) the contents of paper 59 and PIÉRON's distinction between "anticipation," or reaction which is made ahead of time because it has become associated with an an external stimulus occurring before the original stimulus to the reaction, and rhythmic reaction, where the response is made to an internal state of the organism, which has come to be periodically produced. In papers 60 and 63 this distinction is amplified and the general significance of physiological rhythms considered.

$62,64,65,66,67$. The chief point of importance brought out in the discussion of autotomy or self-amputation is PIÉRON's differentiation of a form of the phenomenon which he calls "psychic autotomy," unlike reflex autotomy in the facts that it is made in response to slight stimulation, such as merely holding the member fast, and that it does not occur if the commissures connecting the cerebral ganglia with the ventral ganglia are cut. DRzewina $(30,31)$ sees no reason to distinguish this phenomenon from ordinary reflex autotomy, and has found it occurring after section of the commissures.

68. RETTERER states that actinians in northern seas where the effect of the tides is less marked do not show a tidal rhythm in the laboratory.

69. This paper is a study of the manner in which certain seaside Diptera are adapted to their surroundings. The bodies of most of them are impervious to water; those which are by their manner of life exposed to the wind have a marked tendency to orient to it, or to hide behind shells when it is very strong; other forms resist it by taking very short flights or by bracing themselves with their legs.

70. The following three points are brought out in this study of Actinia equina. (a) 1 he actinian tends to resume the position it had in nature when placed in 


\section{Fournal of Comparative Neurology and Psychology.}

the reverse position in the laboratory. (b) An actinian would not swallow a bit of mollusc attached to a morsel of cork until the cork was removed. A bit of mollusc and a piece of another actinian, of a different species, being placed on different parts of the disk, the former was swallowed and the latter rejected. (c) The foot "prefers" to attach itself to a rough surface if offered the "choice" between this and a smooth one.

Bons, G.

\section{BIBLIOGRAPHY.}

I. L'individualite psychique chez les Vers, les Echinodermes, et les Insectes. Bull. Inst. gén. psych., vol. 6, p. 115 . 1 go6.

2. Sur le photrotopisme de l'Acanthia lectularia Fabr. C.r. Soc. Biol., vol. 6o, p. 520.1906.

3. Sur l'adaptation des réactions phototropiques. C.r. Soc. Biol., vol. 60, p. $5^{84}$. 1906.

4. Sur les courbures dues à la lumière. C. r. Soc. Biol., vol. 6I, p. 420.1906.

5. Sur des mouvements de roulement influences par la lumière. C.r. Soc. Biol., vol. 6r, p. 468. 1906.

6. Mouvements en relation avec l'assimilation pigmentaire chez les animaux. C. r. Soc. Biol., vol. 61, P. 527. 1906.

7. La finalité dans l'étude des mouvements. C. r. Soc. Biol., vol. 6r, p. 570.1906.

8. La persistance du rythme des marées chez l'Actinia equina. C. r. Soc. Biol., vol. 61, p. 661.1906.

9. Le rythme des marées et la matière vivante. Réponse a M. Lapicque. C. r. Soc. Biol., vol. 61, p. 708.1906.

10. Observations sur les papillons du rivage de la mer. Bull. Inst. gen. psych., vol. 6, p. 285 . I goo.

11. Les tropismes, les réflexes, et l'intelligence. Anri. psych., vol. 12, p. 137. 1906.

12. Quelques chiffres rélatifs au rythme vital des Convoluta. C.r. Soc Biol., vol. 62, p. 5I. I907.

13. Sur l'impossibilité d'étudier avec une precision mathematique les oscillations de l'etat physiologique chez les animaux littoraux. C. r. Soc. Biol, vol. 62, p. 211. 1907.

14. L'influence de l'éclairement passe sur la matière vivante. C. r. Soc. Biol., vol. 62, p. 292. 1907.

15. Introduction à la psychologie des animaux à symetrie rayonnee. I. I.es etats physiologiques des Actinies. Bull. Inst. gen. psych., vol. 7, pp. 81, 135. 1907.

16. L'influence de l'agitation de l'eau sur les Actinies. C. r. Soc. Biol., vol. 62, p. 395. 1907.

17. Le rythme nycthemeral chez les Actinies. C. r. Soc. Biol., vol. 62, p. 473. 1907.

18. A propos du procès-verbal. Le ralentissement ct l'accélération des oscillations des Convoluta. C. r. Soc. Biol., vol. 62. p. 564. 1907.

19. Les tropismes, la sensibilité differentielle, et les associations chez le Branchellion de la Torpille. C. r. Soc. Biol., vol. 63, p. 545. 1907.

20. A propos des lois de l'excitabilité par la lumière. I. Le rétour progressif a l'etat d'immobilité apres une stimulation mécanique. C. r. Soc. Biol., vol. 63, p. 655.1907.

21. A propos des lois, etc. Il. Du changement du signe du phototropisme en tant que manifestation de la sensibilité differentielle. C. r. Soc. Biol., vol. 63, p. 756.1907 .

22. L'acquisition des habitudes chez les animaux. Ann. psych., vol. 13, p. 170. 1907.

23. Sur la rôle et la protection des organes des sens chez les échinodermes. C. r. Soc. Biol., Biol., vol. 64, p. 277 . I908.

24. Sur les mouvements rotatoires des Étoiles de mer et les Ophiures. C. r. Soc. Biol., vol. 64, p. 532. 1908.

25. De lacquisition des habitudes chez les fitoiles de mer. C. r. Soc. Biol., vol. 64, p. 633. 1908.

26. Scissiparitc et autotomie chez les Actinies. C. r. Soc. Biol., vol. 64, p. 936. 1908.

27. Introduction à la psychologie des animaux a symetrie rayonnée. II. Les essais et erreurs chez les Etoiles de mer et les Ophiures. Bull. Inst. gen. psych., vol. 8, p. 21.1908.

Bonn, G. and Pitron, H.

28. Le rythme des marées et le phenomene de l'anticipation reflexc. C. r. Soc. Biol., vol. 6r, p. 660.1906. 


\section{Washburn, Comparative Psychology.}

BonnixR, G.

29. Le socialisme chez les abeilles. Bull. Inst. gén. psych., vol. 7, p. 397. I907.

Drzewiva, A.

30. Sur la pretendue autotomie psychique. C. r. Soc. Biol., vol. 63, p. 459.1997.

3t. Y a-t-il une différence effective entre la prétendue autotomie psychique et l'autotomie réflere? Reponse a M. Pieron. C. r. Soc. Biol., vol. 63, p. 493. Igom.

32. Les variations periodiques du signe du phototropisme chez les Pagures misanthropes. C. r. Acad. Sci., Paris, Dec. 9, 1907 .

33. De l'hydrotropisme chez les Crabes. C. r. Soc. Biol., vol. 64, p. 1009. 1908.

FAurt-Frenizt, E.

34. Organisation, fonctionnement, et reactions individuelles chez les Cytozoaires. Bull. Inst. gen. psych., vol. 6, p. 305. 1906.

35. L'organisation, le fonctionpement, et les réactions individuelles chez les Cytozoaires. Bull. Inst. gen. psych., vol. 7, p. 75. 1907.

36. Reactions de deux Infusoires ciliés. Bull. Inst. gén. psych., vol. 7, p. 308. Igo7.

37. Les conditions organiques de comportement chez les Cytozoaires: l'Urostyla grandis. Bull. Inst. gen. psych., vol. 7, p. 441. rgo7.

FAuvel, P. and Bohn, G.

38. Le rythme des marées chez les Diatomees littorales. C. r. Soc. Biol., vol. 62, p. 121. 1907. Forel, A

39. La mémoire du temps et l'association des souvenirs chez les Abeilles. Bull. Inst.gén. psych., vol. 6, p. 258 . 1906.

Hachet-SoupLet.

40. Le criterium de l'instinct. Bull. Inst. gen. psych., vol. 7, p. 72. 1907.

41. Sur un projet de création d'une Section d'etude expérimentale de dressage scientifique à l'Institut général psychologique. Bull. Inst. gén. psych., vol. 7, p. 187. 1907.

42. Les chiens sauveteurs et la Zoopedie. Bull. Inst. gén. psych., vol. 7, p. 45I. 1907.

LAPICQCE, L.

43. Sur les fonctions rythmiques des animaux soumis a l'alternance des marées. Observavation sur la note de M. Bohn. C. r. Soc. Biol, vol. 61, p. 707. 1906.

44. Sur la précision dans la question du rythme des marées. C. r. Soc. Biol., vol. 62, p. 302. 1907 .

Lecarrion, A.

45. Réponse a M. Bohn, C. r. Soc. Biol., vol. 62, p. 475. 1907.

46. Les inetincts et le psychisme des Araignees. Bull. Inst. gen. psych., vol. 6, 127. 1906.

47. Notes complémentaires sur les moeurs des Araignées. I. Influence de la nutrition sur la réproduction d'Ageléna labyrinthica Cl. C. r. Soc. Biol., vol. 62, p. 334. 1907 .

Marage.

48. Notes complémentaires, etc. ШI. Nature et importance des soins que certaines femelles donnent a leur progeniture. C. r. Soc. Biol., vol. 63, p. 668.1907.

49. Contribution a l'étude de l'audition des poissons. C. r. Acad. Sci. Paris, vol. 143, p. 852 . 1906.

Martin, L.

50. La mémoire chez Convoluta roscoffensis. C. r. Acad. Sci, Paris, vol. 145, p. 555.

Mentanux, A.

51. Une observation sur le sens olfactif à distance chez les Fourmis. Bull. Inst. gén. psych., vol. 6. p. 302 . 1906 .

52. Questions de morphologie et de psychologie chez les oiseaur. Bull. Inst. gén. psych.,

Pitron, $\mathrm{H}$. vol. 7, p. 427.1907 .

53. Contributions à la psychologie des Actinies. Bull. Inst. gen. psych., vol. 6, p. 40. 1906.

54. Contribution a l'etude des rapports ethologiques des Crabes et des Actinies. Bull. Inst. gen. psych., vol. 6. p. 98.1906.

55. Contribution à la psychophysiologie des Actinies. Les réactions de l'Actinia equina. Bull. Inst. gen. psych. vol. 6, p. 146. 1906.

56. Généralité du processus olfactif de reconnaissance chez les Fourmis. C. r. Soc. Biol., vol. 61 , p. 385 . 1906.

57. Exceptions et variations dans le processus olfactif de reconnaissance chez les Fourmis. C. r. Sor. Biol., vol. 6I, p. 433. 1906. 


\section{Fournal of Comparative Neurology and Psychology.}

Pitron, H.

58. Le mécanisme de la reconnaissance chez les Fourmis. Rôle des données olfactives. C. $r$. Soc. Biol., vol. 61, p. 471 , 1906.

59. La réaction aux marées par anticipation réflexe chez Actinia equina. C. r. Soc. Biol., vol. 61, p. 658.1906.

6o. La question des rythmes spontanés et des phenomènes d'anticipation en biologie. $C . r$. Biol., vol. 62, p. 51.1907.

61. L'adaptation à la récherche du nid chez les Fourmis. C. r. Soc. Biol., vol. 62, p. 216.1907.

62. Autotomie et 'autospasie'. C. r. Soc. Biol., vol. 63, p. 425. 1907.

63. Des phenomènes d'adaptation biologique par anticipation rythmique. C. r. Acad. Sci., Paris, vol. 144, p. $13^{8}$. 1907 .

64. Sur une prétendue réfutation de l'autotomie psychique. Résponse à Mlle. Drzewina. C. r. Soc. Biol., vol. 63, p. $46 \mathrm{r}$. 1907 .

65. L'autotomie protectrice réflere chez les Orthoptères. C. r. Soc. Biol, vol. 63, p. 463 . 1907.

66. L'autotomie volontaire des decapodes. Quelques idées et quelques faits. C. r. Soc. Biol., vol. 63, p. 517. 1907 .

67. L'autotomie évasive chez les Orthopteres. C. r. Soc. Biol., vol. 63, p. 186. 1907.

RETTERER, E.

68. À propos du rythme des marées et de la matière vivante. C. r. Soc. Biol., vol. 62, p. 186 . 1907 .

Roubaud.

69. Instincts, adaptation, resistance au milieu chez les Mouches des rivages maritimes. Bull. Inst. gérn. psych., vol. 7. p. 60 . I907.

VAN DER GHinst, $\mathbf{I}$.

70. Quelques observations sur les Actinies. Bull. Inst. gén. psych., vol. 6, p. 267. 1906. 